\title{
Sayyang Pattuqduq as a Mandarese Identity in the Hyperreality Post-truth Era
}

\author{
Irfa Aulia Dwiputri ${ }^{1, *}$ Rumiwiharsih $^{2}$
}

\author{
${ }^{1}$ Graduate School of Art Education, Yogyakarta State University, Yogyakarta 55281, Indonesia \\ ${ }^{2}$ Faculty of Languages and Arts, Yogyakarta State University, Yogyakarta 55281, Indonesia \\ *Corresponding author. Email: irfaauliadwiputri@gmail.com
}

\begin{abstract}
This study aims to examine the condition of local wisdom-based arts in the hyperreality-post truth era. Art in the perspective of local wisdom has undergone a number of changes or shifts along with the emergence of the hyperreality era. This study focuses on people perspective which is based on the perception of reality in the hyperreality-post truth era. This study employed a qualitative approach. Data were collected from several pieces of literature, cultural documentation, and interviews with cultural activists about hyperreality-post truth and traditions in Mandar (an ethnic group in the Indonesia province of West Sulawesi) culture in order to provide a more comprehensive perspective. In general, these changes or shifts can be viewed from the values that underlie a tradition and the messages carried in that tradition.
\end{abstract}

\section{Keywords: Hyperreality Post-Truth, Tradition, Sayyang Pattuqdu}

\section{INTRODUCTION}

Indonesia has a variety of cultures in its regions. The culture in an area has its characteristics, shown from its arts, foods, customs, and religious events. Mandar, one of the four major ethnic groups in Sulawesi island, is known to have a variety of cultures that are still preserved today. Music, food, religious events serve as tourist attractions in this area. One of the most interesting attractions is Sayyang Pattuqduq [1].

Cultural shifts are closely related to the characteristics of the civilizations in the era of hyperreality. The concept of hyperreality was first introduced by Jean Baudrillard. Baudrillard defines hyperreality as the way our perception of the world is increasingly dependent on simulations of reality, and as a result, we become an information society [2]. This concept can be translated by perceiving surroundings that are very dependent on reality simulations because of the massive information perceived by people.

The characteristics of society in the hyperreality era also influence cultural characteristics, especially in traditions based on local wisdom. In this article, the influence of hyperreality is examined from the perspective of tradition in Mandar society.

Sayyang Pattuqduq means dancing horse [3]. In this ritual, the two front legs of a horse move in a constant pattern and an interesting rhythm. The music is played from the tambourine of the Mandar tribe. The horse movement is more beautiful when it moves its' head in harmony with the leg movement. Occasionally, the front body will lift upward when the rider performs a certain trick.

In general, Sayyang Pattuqduq is performed in two big events in Mandar. Using the same musical instruments, Sayyang Pattuqduq is usually performed in the month of Mawlid and at wedding ceremonies [4]. Sayyang Pattuqduq performed in the Mawlid events is a form of reward to children who have finished reciting Al-Quran. Those children parade around the village [5]. This parade is believed to be able to motivate other children to recite Al-Quran. In wedding ceremonies, Sayyang Pattuqduq serves as a ritual to accompany the ritual of parading the bride around her groom's house.

In the Mawlid events, if the child being parade is a girl, a woman should accompany her and sit in the front. 
They wear traditional costumes from the Mandar region, so they look so elegant. If a boy is being paraded, he should wear clothes in Arabic style. This is an explicit example that Sayyang Pattuqduq is a culture that is integrated with Islamic values.

Several references are mentioning the origin of Sayyang Pattuqduq. It is believed that this old tradition first started in the 16th century [6]. Once upon a time, when the King of Balanipa was about to hunt in the wilderness, he found a wild horse that was so difficult to tame. The King then took the initiative to bring the horse to the kingdom. A few days later, the empress came to the stable because she was curious about the animal that had just been caught by the King. She then got on the horse and immediately, and then the horse showed a movement that looked like a dance. A tambourine was then played along with the horse dance and along with the Mandarese poetry.

Initially, this dance was only performed in the palace area, but as the Mandar ulama arrived, the performance that was originally exclusive for the royals are available for the people in general. This is due to the concept taught by the ulama to integrate Islamic values with local cultures. Moreover, this is the reason why Sayyang Pattuqduq is now performed in the Mawlid celebration when local people are motivated to celebrate the birth of Prophet Muhammad [1].

Sayyang Pattuqduq is considered an effective communication medium to teach the Mandar community, not only about the birth of the Prophet Muhammad, but also the ukhuwah (Islamic-based relation). When celebrating Mawlid, all people in the village serve traditional food to welcome guests who watch the horse parade. The people in the village also prepare all things needed for the celebration.

Some instruments to perform Sayyang Pattuqduq are explained in the following.

1. A horse is the most important part of the performance. The horse should be well trained and able to follow tambourine play well. The variation of the movements in Sayyang Pattuqduq is when the horse lifts half of its body.

2. Pessawe is a woman sitting at the front to accompany a girl (todisaiyyang). This woman dresses in a Mandarese costume. Pessawe are usually beautiful and attractive. The term Pessawe also refers to either one or two boys sitting on a horse.

3. Todisaiyyang is a girl who has completed reciting Al-Quran. She wears Mandarese costume which is modified into a gown usually worn by Hajj.

4. Pesarung are men standing in all four sides of a horse to guard Pessawe and Todisaiy to be able to sit on the horseback stably. During the parade, they are responsible for the riders' safety.

5. Pambawa La'lang is in charge of carrying an umbrella to protect Pessawe in order to avoid sunburn. The umbrella is decorated with various colored pieces of paper. It is then tied to a bamboo approximately 3 meters long.

6. A tambourine is used to accompany the horse dance. The music from the tambourine is also an important part of this performance because, without a tambourine, Sayyang Pattuqduq procession would be so bland. There is no definite number of tambourine drummers. The music group usually consists of 8-12 people. The tambourine used are now varied, from the small to the bigger ones. Moreover, nowadays music groups add modern instruments to create the music.

7. Kalindaqdaq is a typical Mandarese poem that is usually sung in front of a horse in the Sayyang Pattuqduq performance. The lyrics are about a compliment to the woman sitting on a horse and usually contain very subtle phrases or sentences. During its development, kalindaqdaq has started to use the Indonesian language and does not follow the usual poetic patterns used when the first kalindaqdaq appeared in Sayyang Pattuqduq. As if the horse understands what is conveyed by the person, at the end of each sentence, the horse is more enthusiastic in dancing, shaking his head [1].

This article begins with an introductory section that contains information about hyperreality in general and Sayyang Pattuqduq tradition in particular. In the second part, research methods, data collection techniques, and data analysis are explained. Then, the data are discussed explicitly in the fourth section, and the conclusion is in the fifth section.

\section{RESEARCH METHOD}

The qualitative research method was the basis in this study that tried to explore the shift of art in the local wisdom context. In general, the data were collected through literature study, documentation, and interviews. The references used were books, journal articles related to hyperreality and the Sayyang Pattuqduq tradition. The documentation materials were obtained from sources in the form of Sayyang Pattuqduq performances.

To complement the data from literature and documentation, researchers conducted interviews with experts in culture, especially those having knowledge of local wisdom. Then, an art education teacher from SMPN 3 Poliwali, Warlia Rahman was interviewed. After all, data were collected, the researchers analyzed the data using the qualitative descriptive analysis 
method by analyzing, describing, and summarizing various conditions and situations from various data collected in the form of interviews or observations about the problems occurring in the field.

\section{RESULT AND DISCUSSION}

Sayyang Pattuqduq is a legacy from the ancestors. This ritual is done as a form of reward for children who can finish reciting Al-Quran. Besides, Sayyang Pattuqduq is an acculturation of Mandar culture. Thus, religious values are deeply rooted in this tradition and are always attached to various performance contexts.

In Mandar, dances are generally performed in ceremonies for worshiping gods and ancestors. Sayyang Pattuqduq has a relatively different function from the general dances. This dance was basically created as a form of reward to children who are able to recite AlQuran.

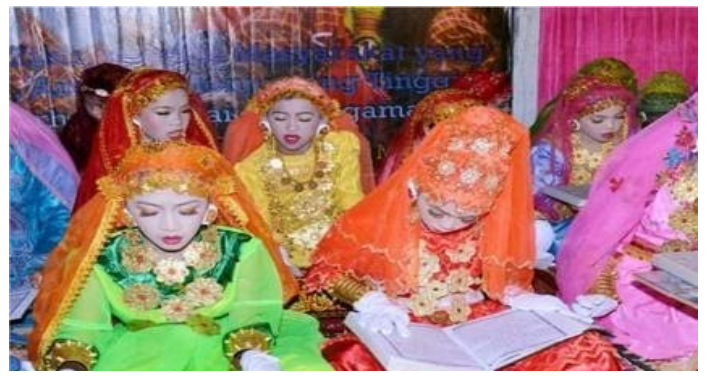

Figure 1 Celebrating the moment of reciting Al-Quran

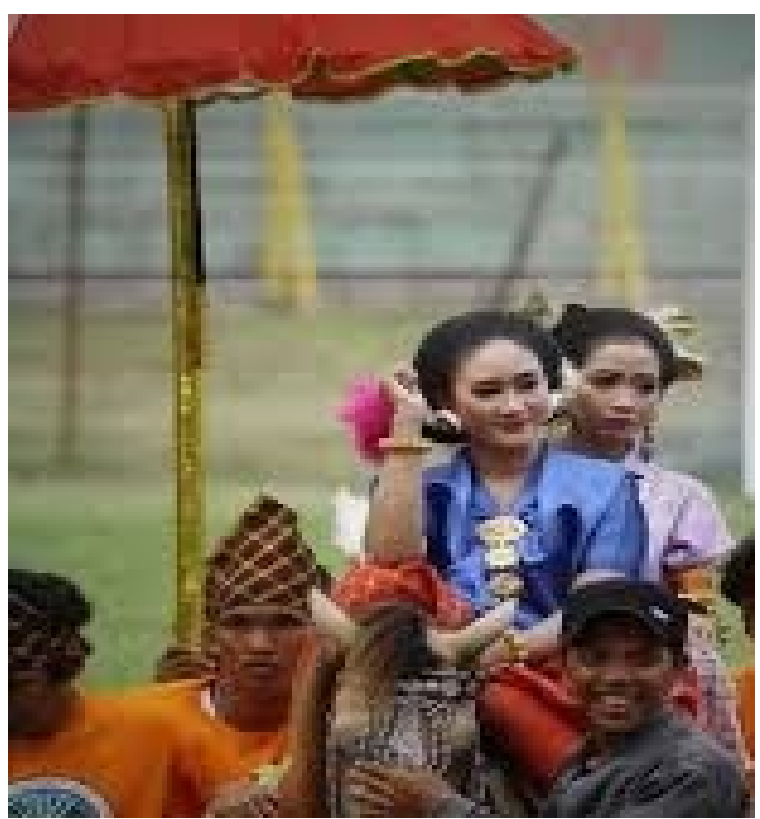

Figure 2 Sayyang Pattuqdu performed at a festival

\subsection{Swift of Values in Sayyang Pattuqduq Tradition}

After more than four centuries, Sayyang Pattuqduq began to undergo a number of shifts, especially in Pessawe, Todisaiyyang, musical instruments used to accompany the dance or kalindaqdaq, and its purpose [7]. The women riding the horse (Pessawe) used to be carefully selected as they should pass the criteria. However, nowadays, the criteria seem to be ignored because the most important thing is the celebration.

The second shift is the purpose of performing the dance. Sayyang Pattuqduq was only performed at royal events, but now it is performed to welcome government guests and to celebrate certain festivals. Some people believe that the shift has reduced the sacred values of Sayyang Pattuqduq, but some argue that it is done to preserve the culture.

Another shift and the most concerning is the lack of religious values that the dance used to show when it was first introduced. In the past, Sayyang Pattuqduq was performed to celebrate and appreciate the birth of the Prophet, but today in some areas, Sayyang Pattuqduq is performed for fun, so it no longer delivers the religious message.

Because it was only performed in royal events, children from the common family were very happy to be able to ride the horse when they were able to finish reciting Al-Quran. They experienced being the royals. Thus, they were motivated to recite Al-Quran. However, this tradition is now done by both common people and the royals because it has lost the religious meaning.

\subsection{Hyperreality Era and Its Impacts on Tradition}

Baudrillard's concept of simulation emphasizes the creation of reality through a conceptual model or something related to "myths" that cannot be seen in reality. This model determines our view of reality. Everything that can attract human interest, such as art, homes, household needs, and so on - is broadcast through various media with ideal models. This is where the boundaries between simulation and reality get mixed up, creating hyperreality where the real and the unreal becomes unclear.

In another context, Jean Baudrillard uses the term hyperreality to describe the manipulation of media (in terms of distortion). The hyperreality of communication, media, and meaning creates a condition, where everything is considered more real than reality and faulty is considered truer than truth.

In general, there is not much research that explores the relationship between the era of hyperreality and the existence of tradition in the context of local wisdom. 
However, after examining the concept of hyperreality and the dynamics that accompany it in a social context, there is a concept that can be drawn in connection with changes in tradition. The first change is that people tend to abandon the reality of the "origin" of the traditional creation itself. Thus, some people incorporate the elements of imagination, which in their perspective is considered a reality, and then integrated into the elements of dance.

The second change is on the "message" that the dance used to try to deliver in various events. This condition shows that the meaning swift of the dance is accepted by the community in the hyperreality-post truth era.

The message in Sayyang Pattuqduq tradition has somewhat changed. This tradition was related to religion. However, in this day and age, this tradition tends to have no message and only function as entertainment under certain circumstances.

\subsection{The Existence of Sayyang Pattuqduq}

Sayyang Pattuqduq has different regulations from when it was performed before the hyperreality-post truth era. From the aspects of performance, it was shown in the palace area only. However, as Islam came to Mandar, Sayyang Pattuqduq experience a function swift.

In the hyperreality era, Sayyang Pattuqduq is transformed into a creative dance that functions as a means of communication that indirectly builds the Mandarese identity. There is no in-depth study on to what extent hyperreality- post-truth era has affected Sayyang Pattuqduq tradition. However, from the analysis of literature, as well as documentation and information collected, it is found that Sayyang Pattuqduq has relatively sifted.

\section{CONCLUSION}

The era of hyperreality has had significant influences on culture, especially in the context of local wisdom. There are two fundamental changes in the characteristics of the tradition which have changed along with the trend of the hyperreality-post truth era. The first change is in the value that underlies a tradition, and the second is in the message conveyed by a tradition. Regardless of the nature of a tradition that follows the characteristics of the civilization that accompanies it, the era of hyperreality has brought its color to the tradition.

Studies on the influence of the post-truth-era hyperreality on local wisdom-based art are still very limited in number. Therefore, more studies are needed in the future to get a more comprehensive perspective about the influence of this era. In addition, the context of local wisdom from one region to another is relatively different. With their distinctive characteristics, the art will show different impacts of the hyperreality-posttruth era.

\section{REFERENCES}

[1] Asdy, H. A. Jelajah Budaya: Mengenal Kesenian Mandar [Cultural Exploration: Getting to Know Mandar Art]. Makassar: Yayasan Maha Putra, 2009.

[2] Tiffin, John, and Nobuyoshi Terashima, eds. Hyperreality: Paradigm for the third millenium. Psychology Press, 2001.

[3] Perry, Nicholas, and Nick Perry. Hyperreality and global culture. Psychology Press, 1998.

[4] Asdy, H. A. Mengenal Pattu'du Tradisional Mandar [Getting to know Mandar Traditional Pattu'du]. Makassar: Yayasan Maha Putra, 2019.

[5] Ruhiyat. Tradisi Sayyang Pattu'du di Mandar [Sayyang Pattu'du tradition in Mandar]. Jurnal Studi Agama dan Masyarakat 13(1), 2013. URL: https://media.neliti.com/media/publications/132163 -ID-tradisi-sayyang-pattudu-di-mandar-studi.pdf

[6] Alimuddin, M. R. Mandar Nol Kilometer [Zero Kilometer Mandar]. Yogyakarta: Ombak, 2013.

[7] Najah, Naqib. Suku Mandar Pelaut Ulung yang Kaya Pekerti [The Mandar Tribe, Brilliant Sailors who are Rich in Character]. Makassar: Aquarich, 2015. 